Journal of Extension Education

Vol. 29 No. 2, 2017

DOI:https://doi.org/10.26725/JEE.2017.2.29.5838-5849

\title{
Utilization Pattern of Extension Tools and Methods by Agricultural Extension Agents
}

\section{M.Surudhi ${ }^{1}$, M.Asokhan ${ }^{2}$ and R.Arunachalam ${ }^{3}$}

\begin{abstract}
A study was conducted in Krishnagiri district of Tamil Nadu state to understand the utilization pattern of extension tools and methods by the agricultural extension agents. As ICT revolution is slowly conquering the rural sector, it becomes imperative that the agricultural extension agents transform themselves to the changing times and develop competencies in utilizing these ICTs. The study explored the usage of various extension tools and methods by the change agents and the constraints faced in utilizing them. The findings revealed that the extension functionaries frequently used the individual contact methods viz., telephone, office calls and farm and home visits in the process of transfer of technology. Least efforts were made in sending SMS based communication. Meetings were the common and frequently adopted group contact method. Demonstrations, farmer field school, farmer interest groups, field trips and farmer training programmes were moderately adopted. Posters, leaflets and pre-season campaigns were the widely adopted mass contact methods. They possess least skill in utilizing farm magazines and presenting television and radio programmes.
\end{abstract}

Keywords: Extension method; Extension agent; ICT; individual contact method; group contact method; mass contact method

\section{INTRODUCTION}

Agricultural extension has a wider connotation, from providing non-formal - agriculturally related continuing adult education for multiple audiences viz., farmers, youth and community, to raise the production and profitability of their farms (agricultural production performance) and to providing a wide range of agricultural development tasks, such as credit, supplies, marketing and markets (agricultural process development). Today, educational programmes delivered by extension agents are more varied than ever and will continue to change to meet the needs of the clientele they serve. Given the need for sustainability in today's world, Agricultural Extension Agents (AEAs) are expected to know more, and meet the increasing demands of a diverse farmer population. 
Globally, some 6,00,000 extension workers are engaged in the provision of agricultural information to farmers (Maalouf et.al., 1991), of which 95\% is carried out by public extension (Davidson et. al., 2001). However, serious reservations are being expressed about the performance and capability of this sector, placing the future of the public extension system in doubt. Rogers (1987) argued that the performance of public agricultural extension in developing countries has been disappointing and has failed to transfer agricultural technology to the farmers.

The challenge before the extension worker is that he needs to acquaint with the ever expanding pool of scientific knowledge to address the farm situation and become proficient in utilizing the varied options of extension methods that are developing day-by-day. With increasing penetration of internet and mobile telephony into the rural areas, the present day extension is dominated by $\mathrm{e}$ - platform and $\mathrm{m}$ - platform of extension service. The developments in the mass media are opening up a bouquet of opportunities to the extension worker (Shuwa et.al, 2015). Mass media and Information and Communication Technologies have been widely used to supplement and complement the extension service. Group approaches in extension has been promoted extensively. As the information and communication revolution is conquering the rural sector, it becomes imperative that the agricultural extension agents transform themselves to the changing times and develop competencies in utilizing these ICTs. In this context, the study was conceived with the following specific objectives;

1. To study the usage pattern of individual, group and mass contact methods

2. To rank the extension methods based on the preference of usage by the extension functionaries

3. To enumerate the constraints faced by the extension personnel in utilization of extension tools and methods.

\section{METHODOLOGY}

The extension functionaries of the State Department of Agriculture in the entire Krishnagiri district were considered for the study. A total of 98 extension functionaries available in the district in various capacities formed the population for the study. Ex post facto research design was used and data were collected by using structured and standardized interview schedule by personal face-toface interview.

The study utilized the classification of Wilson and Gallup (1954) for the purpose of studying the pattern of utilization of extension methods and tools. The extension methods and tools were classified into individual contact methods, group contact methods and mass contact methods and their usage and frequency of usage was studied. By 
having elaborate discussions with social scientists, local extension functionaries and also the local progressive farmers, thirty nine extension methods and tools were finalized, which consisted of six items under individual contact methods, fifteen items under group contact methods and eighteen items under mass contact methods.

The pattern of utilization of extension methods and tools were studied on two dimensions viz., usage and frequency of usage. The scoring pattern utilized by Anand (2014) was adopted with slight modifications.

\section{FINDINGS AND DISCUSSION}

\section{Usage of Individual Contact Methods}

The findings on the usage of individual contact methods showed that all the six methods selected for the study were used by the extension functionaries. It was found that 100 per cent of the extension functionaries were using telephones and office calls. Telephones were utilized by 89.80 per cent of them regularly and 72.40 per cent of them were utilizing office calls regularly. The findings of the study found 100 per cent usage of telephones by the extension functionaries and support this development.

Among ICTs, impressive penetration of mobile phones in many of the developing countries has changed the agricultural communication process and mobile phones have made personal communications readily accessible to the common man.

The second individual contact with 100 per cent usage was office calls. Just as the extension agent visits the farmer, from time to time, the farmer may also visit the agent at his office to obtain some information, assistance in diagnosis and treatment of some disease or deficiency, or securing some inputs, credit etc. This practice is becoming quite popular these days and many farmers visit the extension agent and this is a reflection of the interest which the agent might have aroused among the local farmers. The study found that 72.40 per cent of the extension functionaries had office calls regularly, which reflects the confidence the local farmers had on the extension agent.

Farm and home visits were used by 95.90 per cent of the extension functionaries and 66.30 per cent of them used it regularly. These visits help the extension functionaries to get a better understanding of the farm and home conditions of the farmer and maintain a personal rapport. The regular usage of this method by more than sixty per cent of the extension functionaries might be due to added advantage they get to know about their clients personally which would assist them in providing a tailor made extension advice to the particular farmer. 
Table 1.

Distribution of Extension Functionaries According to Usage and Frequency of Usage of Individual Contact Methods

$(\mathrm{n}=98)$

\begin{tabular}{|c|l|c|c|c|c|c|c|c|c|}
\hline \multirow{2}{*}{$\begin{array}{c}\text { S1. } \\
\text { No. }\end{array}$} & \multirow{2}{*}{$\begin{array}{l}\text { Contact } \\
\text { method }\end{array}$} & \multicolumn{2}{|c|}{ Usage } & \multicolumn{6}{c|}{ Frequency of usage } \\
\cline { 3 - 10 } & & Freq. & $\%$ & Freq. & $\%$ & Freq. & $\%$ & Freq. & $\%$ \\
\hline 1 & Telephones & 98 & 100.00 & 88 & 89.80 & 10 & 10.20 & - & - \\
\hline 2 & $\begin{array}{l}\text { Farm and } \\
\text { home visits }\end{array}$ & 94 & 95.90 & 65 & 66.30 & 28 & 28.60 & 1 & 1.00 \\
\hline 3 & Office calls & 98 & 100.00 & 71 & 72.40 & 25 & 25.50 & 2 & 2.00 \\
\hline 4 & $\begin{array}{l}\text { Circular } \\
\text { letters }\end{array}$ & 57 & 58.20 & 13 & 13.30 & 35 & 35.70 & 9 & 9.20 \\
\hline 5 & SMS & 36 & 36.70 & - & & 7 & 7.10 & 29 & 29.60 \\
\hline 6 & Email & 60 & 61.20 & 4 & 4.10 & 48 & 49.00 & 8 & 8.20 \\
\hline
\end{tabular}

It could be seen from the table that, E-mails, circular letters and short messaging service were used by 61.20 per cent, 58.20 per cent and 36.70 per cent of the respondents respectively. The emails were used occasionally by 49.00 per cent of the respondents. The usage of emails by extension functionaries were mainly for official purposes rather than for contacting the farmers. The recent trend of usage of emails for official communication in government departments might have made many of the extension functionaries, at least at the middle and top level utilize it occasionally. Similar is the case with circular letters, which was used by 58.20 per cent of the extension functionaries.

Though Short Messaging Service (SMS) was used by 36.70 per cent of the respondents, only 29.60 per cent of them used it as an extension tool. Though text messaging offers significant advantage over voice-based delivery in terms of convenience and content flexibility, literacy of the farmers is a concern and most farmers preferred voice calls over SMS. Similar findings were also reported by Jayakumar et al., (2015). Moreover, merely receiving messages over mobile phone will not motivate the farmers to start using this information or apply as recommended.

\section{Usage of Group Contact Methods}

Out of the fifteen group contact methods selected for the study, only twelve were used by the extension functionaries. Remaining three methods viz. audio programmes, video programmes and through farmer producer organizations 
were not used by any of the extension functionary. As given in Table 2, 100 percent of the extension functionaries used meetings for their extension activities and 83.70 per cent of them used meetings regularly. Group meetings formed the most commonly used group contact method, possibly because of the advantage of delivering the information to a group of farmers at the same time at a lower cost as well as being able to get their feed backs.

More than fifty per cent of the extension functionaries used method demonstrations, result demonstration and through farmer field school. The findings are in accordance with the findings of Ghanghas (2011) who reported that the most commonly used group contact methods were group meetings, demonstrations and crop competitions.

Forty to fifty percent of the extension functionaries used farmer trainings, field trips and through farmer interest groups. Organizing farmer trainings and field trips are costly affairs and would have possibly restricted their usage. The advantages of using farmer field schools in promoting IPM has been well understood and the concept is being promoted widely through ATMA. Hence, 52.00 per cent of the respondents reported to have used it.

Table 2.

Distribution of Extension Functionaries According to Usage and Frequency of Usage of Group Contact Methods

$(\mathrm{n}=98)$

\begin{tabular}{|c|l|c|c|c|c|c|c|c|c|}
\hline \multirow{2}{*}{$\begin{array}{c}\text { S1. } \\
\text { No. }\end{array}$} & \multirow{2}{*}{$\begin{array}{l}\text { Group contact } \\
\text { methods }\end{array}$} & \multicolumn{2}{|c|}{ Usage } & \multicolumn{5}{c|}{ Fegularly } & \multicolumn{2}{c|}{ Occasionally } & \multicolumn{2}{c|}{ Rarely } \\
\cline { 3 - 10 } & Freq. & $\%$ & Freq. & $\%$ & Freq. & $\%$ & Freq. & $\%$ \\
\hline 1 & $\begin{array}{l}\text { Method } \\
\text { demonstration }\end{array}$ & 52 & 53.10 & 2 & 2.00 & 47 & 48.00 & 3 & 3.10 \\
\hline 2 & $\begin{array}{l}\text { Result } \\
\text { demonstration }\end{array}$ & 65 & 66.30 & 8 & 8.20 & 50 & 51.00 & 9 & 9.20 \\
\hline 3 & $\begin{array}{l}\text { Frontline } \\
\text { demonstration }\end{array}$ & 24 & 24.50 & - & - & 21 & 21.40 & 3 & 3.10 \\
\hline 4 & Lectures & 22 & 22.40 & - & - & 21 & 21.40 & 1 & 1.00 \\
\hline 5 & $\begin{array}{l}\text { Farmer } \\
\text { training }\end{array}$ & 43 & 43.90 & 6 & 6.10 & 34 & 34.70 & 3 & 3.10 \\
\hline
\end{tabular}


Utilization Pattern of Extension Tools and Methods by Agricultural Extension Agents

\begin{tabular}{|c|l|c|c|c|c|c|c|c|c|}
\hline \multirow{2}{*}{$\begin{array}{c}\text { S1. } \\
\text { No. }\end{array}$} & \multirow{2}{*}{$\begin{array}{l}\text { Group contact } \\
\text { methods }\end{array}$} & \multicolumn{2}{|c|}{ Usage } & \multicolumn{6}{c|}{ Frequency of usage } \\
\cline { 3 - 10 } & Freq. & $\%$ & Freq. & $\%$ & Freq. & $\%$ & Freq. & $\%$ \\
\hline 6 & Meetings & 98 & 100.00 & 82 & 83.70 & 16 & 16.30 & - & - \\
\hline 7 & Tours & 21 & 21.40 & - & - & 17 & 17.30 & 4 & 4.10 \\
\hline 8 & Field trips & 45 & 45.90 & 2 & 2.00 & 26 & 26.50 & 17 & 17.30 \\
\hline 9 & $\begin{array}{l}\text { PowerPoint } \\
\text { presentations }\end{array}$ & 29 & 29.60 & - & - & 24 & 24.50 & 5 & 5.10 \\
\hline 10 & $\begin{array}{l}\text { Through } \\
\text { farmer interest } \\
\text { groups }\end{array}$ & 46 & 46.90 & 11 & 11.20 & 22 & 22.40 & 13 & 13.30 \\
\hline 11 & $\begin{array}{l}\text { Through } \\
\text { farmer field } \\
\text { school }\end{array}$ & 51 & 52.00 & 17 & 17.30 & 23 & 23.50 & 11 & 11.20 \\
\hline 12 & $\begin{array}{l}\text { Through } \\
\text { commodity } \\
\text { interest group }\end{array}$ & 5 & 5.10 & - & - & 5 & 5.10 & - & \\
\hline
\end{tabular}

Farmer interest groups have been promoted for quite some time and it was found that 46.90 per cent of the respondents used these groups for information delivery. The advantage of group influence could be utilized effectively by the extension functionary. Though commodity interest groups were used by 5.10 per cent of the respondents, farmer producer companies were not mentioned by any of the respondent.

Lectures, Powerpoint presentations and tours were used by 20.00 to 30.00 per cent of the extension functionaries and most of them used these methods occasionally. Lectures and Power Point presentations are mostly used in campus teaching and in intellectual forums, when coming to rural settings their usage is restricted due to availability of facilities. In the case of tours, programmes like ATMA has specific funds for tour programmes, whereas other schemes do not provide funds for tours. The exorbitant cost involved in organizing tours may possibly be a deterrent in their usage.

\section{Usage of Mass Contact Methods}

Among the eighteen mass contact methods selected in the study, only twelve were used by the extension functionaries. Mass contact methods like 
television, farm journals, news stories, popular articles, feature articles and Kisan melas were not used by any of the extension functionary. Out of the twelve mass contact methods used, only three were used by a large number of extension functionaries. Posters and leaflets were used by more than ninety per cent of the extension functionaries. The next highest mass contact method used was preseason campaigns by 73.50 per cent of the extension functionaries. The findings of the usage of mass contact methods are presented in Table 3.

Poster as a visual media has quite an important role in creating awareness among the farmers, and this is widely accepted by the extension functionaries. The higher percentage of usage could be contributed to this reason. It is quite common to see information on agricultural practices being displayed as posters in our countryside. Though 34.70 per cent of the respondents reported to use posters regularly, 56.10 per cent used it occasionally.

Leaflets were used by 95.90 per cent of the respondents, however only 75.50 per cent of the extension functionaries used leaflets regularly. The handy and precise information content of the leaflet and its attractiveness would have made it quite popular among the farmers. Its popularity among the farmers and the cost effective nature would have made leaflets the most commonly used mass contact method. The other mass contact methods used by large percentage of extension functionaries was preseason campaigns, though most of them $(73.50 \%)$ reported to use that, only 36.70 per cent used that regularly.

It could be seen from Table 3 that most of the mass contact methods were used occasionally by the extension functionaries including posters $(56.10 \%)$ and pre-season campaigns (34.70\%). Similar was the case with charts $(29.60 \%)$, organizing exhibitions $(27.60 \%)$ and participating in farmers' day $(19.40 \%)$. This shows that the extension functionaries were not utilizing the same method repeatedly, providing opportunity for usage of other methods also.

Mass contact methods like television, farm journals, news stories, popular articles, feature articles and Kisan melas were not used by any of the extension functionaries. This is in line with the findings of Melak and Negatu (2012) who found that the bottom and middle level functionaries rarely used radio or television programmes. The nonuse of the above methods might be due to the non-availability of these methods to them. Production of programmes for television might not be within the reach of an extension functionary, similar is the case with the Kisan melas which are difficult to organize. Though farm publications like magazines, journals and news stories have become popular nowadays, only a meagre 3.10 per cent 
of the respondents reported to use farm magazines, while others were not at all utilized. Journalistic skills need to be imparted to the extension functionaries so that they could effectively utilize the mass contact methods like farm magazines, news stories, popular articles and feature articles.

Table 3.

\section{Distribution of Extension Functionaries According to Usage and Frequency of Usage of Mass Contact Methods}

$(\mathrm{n}=98)$

\begin{tabular}{|c|c|c|c|c|c|c|c|c|c|}
\hline \multirow{3}{*}{$\begin{array}{l}\text { S1. } \\
\text { No. }\end{array}$} & \multirow{3}{*}{$\begin{array}{l}\text { Contact } \\
\text { method }\end{array}$} & \multirow{2}{*}{\multicolumn{2}{|c|}{ Usage }} & \multicolumn{6}{|c|}{ Frequency of usage } \\
\hline & & & & \multicolumn{2}{|c|}{ Regularly } & \multicolumn{2}{|c|}{ Occasionally } & \multicolumn{2}{|c|}{ Rarely } \\
\hline & & Freq. & $\%$ & Freq. & $\%$ & Freq. & $\%$ & Freq. & $\%$ \\
\hline 1 & Through Posters & 89 & 90.80 & 34 & 34.70 & 55 & 56.10 & - & - \\
\hline 2 & Through Charts & 33 & 33.70 & 3 & 3.10 & 29 & 29.60 & 1 & 1.00 \\
\hline 3 & Through Leaflets & 94 & 95.90 & 74 & 75.50 & 18 & 18.40 & 2 & 2.00 \\
\hline 4 & $\begin{array}{l}\text { Through } \\
\text { Handouts }\end{array}$ & 33 & 33.70 & 15 & 15.30 & 12 & 12.20 & 6 & 6.10 \\
\hline 5 & $\begin{array}{l}\text { Through } \\
\text { Hoardings }\end{array}$ & 1 & 1.00 & - & - & 1 & 1.00 & - & - \\
\hline 6 & $\begin{array}{l}\text { Through Wall } \\
\text { paintings }\end{array}$ & 10 & 10.20 & 2 & 2.00 & 8 & 8.20 & - & - \\
\hline 7 & $\begin{array}{l}\text { Through Radio } \\
\text { messages }\end{array}$ & 2 & 2.00 & - & - & 2 & 2.00 & - & - \\
\hline 8 & $\begin{array}{l}\text { Through } \\
\text { Newspapers }\end{array}$ & 18 & 18.40 & 1 & 1.00 & 15 & 15.30 & 2 & 2.00 \\
\hline 9 & $\begin{array}{l}\text { Writing for farm } \\
\text { magazines }\end{array}$ & 3 & 3.10 & - & - & 3 & 3.10 & - & - \\
\hline 10 & $\begin{array}{l}\text { Through } \\
\text { organising } \\
\text { exhibitions }\end{array}$ & 27 & 27.60 & - & - & 27 & 27.60 & - & - \\
\hline 11 & $\begin{array}{l}\text { Participating in } \\
\text { farmers' day }\end{array}$ & 20 & 20.40 & 1 & 1.00 & 19 & 19.40 & - & - \\
\hline 12 & $\begin{array}{l}\text { Through } \\
\text { pre-season } \\
\text { campaigns }\end{array}$ & 72 & 73.50 & 36 & 36.70 & 34 & 34.70 & 1 & 1.00 \\
\hline
\end{tabular}


Ranking of Extension Methods based on the Preference of Usage by Extension Functionaries

Out of the thirty nine extension methods selected in all the three categories, thirty were found to be used by the extension functionaries. In order to know which was the most preferred method among the extension functionaries, these methods were organized based on the mean usage score and ranked. Extension methods which were used regularly obtained a maximum score of 8 , while extension methods which were never used obtained a score of 1 .The extension methods based on their mean usage score has been presented in Table 4.

It could be seen that telephones, meetings, office calls, leaflets and farm and home visits were the most preferred extension methods being utilized by most extension functionaries, which is evident from the mean usage score of above 7 out of 8 . These methods are easy to handle and do not require any specialized equipment or instrument for usage, hence became more popular. The next to follow was the posters with a mean usage score of 6.23 out of 8 . These are the time tested and conventional methods, quite popular for adult education throughout the world. Hence their usage by majority of the extension functionaries is understandable.

Pre-season campaign is a routine programme organized by the
Department of Agriculture. Just before the onset of season, programmes are conducted to popularize new varieties and package of practices for specific crops. This might be the reason why pre-season campaigns secured a mean usage score of 5.34. Similar is the case with result demonstrations, numerous demonstration plots could be seen along the roadsides in rural areas, especially to promote SRI, being put up by the Department of Agriculture. Extension functionaries of the Department of Agriculture are involved in setting up these demonstration plots. It is a wellknown fact that adult learners make maximum use of their senses in order to learn effectively and demonstrations enhance the use of their senses.

Table 4.

\section{Distribution of Extension Methods based on Preference of Usage}

$(n=98)$

\begin{tabular}{|c|l|r|}
\hline $\begin{array}{c}\text { S1. } \\
\text { No }\end{array}$ & \multicolumn{1}{|c|}{$\begin{array}{c}\text { Extension contact } \\
\text { methods }\end{array}$} & $\begin{array}{r}\text { Mean } \\
\text { usage } \\
\text { score }\end{array}$ \\
\hline 1 & Telephone call & 7.8 \\
\hline 2 & Meetings & 7.67 \\
\hline 3 & Office calls & 7.41 \\
\hline 4 & Through leaflets & 7.27 \\
\hline 5 & Farm and home visit & 7.1 \\
\hline 6 & Through posters & 6.23 \\
\hline 7 & $\begin{array}{l}\text { Through preseason } \\
\text { campaigns }\end{array}$ & 5.34 \\
\hline 8 & Result demonstration & 4.3 \\
\hline 9 & Circular letters & 3.99 \\
\hline
\end{tabular}




\begin{tabular}{|c|c|c|}
\hline $\begin{array}{l}\text { S1. } \\
\text { No }\end{array}$ & $\begin{array}{c}\text { Extension contact } \\
\text { methods }\end{array}$ & $\begin{array}{l}\text { Mean } \\
\text { usage } \\
\text { score }\end{array}$ \\
\hline 10 & emails & 3.98 \\
\hline 11 & $\begin{array}{l}\text { Through Farmer field } \\
\text { schools }\end{array}$ & 3.72 \\
\hline 12 & Method demonstration & 3.63 \\
\hline 13 & $\begin{array}{l}\text { Through Farmer } \\
\text { interest groups }\end{array}$ & 3.31 \\
\hline 14 & Farmers trainings & 3.26 \\
\hline 15 & Field trips & 2.99 \\
\hline 16 & Through handouts & 2.87 \\
\hline 17 & Through charts & 2.72 \\
\hline 18 & $\begin{array}{l}\text { PowerPoint } \\
\text { presentations }\end{array}$ & 2.38 \\
\hline 19 & $\begin{array}{l}\text { Through organising } \\
\text { exhibitions }\end{array}$ & 2.38 \\
\hline 20 & SMS & 2.24 \\
\hline 21 & Frontline demonstration & 2.16 \\
\hline 22 & Lectures & 2.1 \\
\hline 23 & $\begin{array}{l}\text { Participating farmers } \\
\text { day }\end{array}$ & 2.04 \\
\hline 24 & Tours & 1.99 \\
\hline 25 & Through newspapers & 1.9 \\
\hline 26 & Through wall paintings & 1.55 \\
\hline 27 & $\begin{array}{l}\text { Through commodity } \\
\text { interest groups }\end{array}$ & 1.26 \\
\hline 28 & $\begin{array}{l}\text { Writing to farm } \\
\text { magazines }\end{array}$ & 1.15 \\
\hline 29 & Through radio messages & 1.1 \\
\hline 30 & Through hoardings & 1.05 \\
\hline
\end{tabular}

The other extension methods like emails, circular letters, farmer field schools and method demonstrations were the next to follow with a better mean usage scores. The other eighteen extension methods have obtained a mean usage score of less than 3.5.

\section{Constraints in the Utilization of Extension Methods}

The extension functionaries were asked to enumerate the constraints they faced in the utilization of different extension methods. With regard to the constraints encountered by the extension functionaries in the usage of individual contact methods, more than fifty per cent of the respondents found that the Short Messaging Services (SMS) was not preferred by many farmers and many farmers did not use e mails. Similarly e mails have become the major official communication tool in many of the offices, whether government or private, as reported by 48.98 per cent of the respondents. Most of our farmers are still far away from computers and emails are still in the infancy and needs a long way to go for being an effective extension tool.

A small proportion $(25.00$ to $35.00 \%$ ) of the extension functionaries also reported the lack of time and transport facilities to reach the farmers regularly. Presently, the grass root level workers depend on their personal vehicles for visiting villages.

The exorbitant cost involved in conducting tours and field trips were reported by 63.26 per cent of extension 
functionaries. The absence of facilities to make Power Point presentations, playing video or broadcasting audio programmes in the villages were reported by 58.16 per cent of the respondents. With regard to conducting meetings, the major problem encountered was the meagre attendance on the part of the farmers. More than fifty per cent (54.08\%) of the extension functionaries were complaining about the meagre attendance. The reason for the meagre attendance may be the lack of interest or non-availability of time on the part of the farmers.

The other major problem encountered was in organizing the farmers into groups, which was felt by 50.00 per cent of the extension functionaries. The village factions based on caste and politics make it difficult to bring farmers together. Moreover, it was found that many farmers were not interested or shy in joining groups.

With regard to usage of radio and television to provide extension messages, 40.82 per cent of the extension functionaries were of the opinion that they lack access to these media. The nearest radio and television station is Chennai. Though Bengaluru is nearest to this district, the radio and television station there could not be utilized due to language problem. The high cost of conducting exhibitions and Kisan melas were the problems reported by 55.10 per cent of the extension functionaries.
The usage of magazines, journals etc. were found to be very meagre and the major problem reported for this was that they were not aware of where to send the articles for publication as reported by 40.82 per cent of the extension functionaries. Fifty per cent of the respondents also reported that they lack the expertise in writing feature articles or news stories for magazines or journals. Lack of time for writing the articles was reported by 38.78 per cent of the respondents.

Even though there were many constraints expressed by the extension functionaries in the utilization of different extension methods in their process of transfer of technology almost all the constraints could be well addressed by conducting appropriate training programmes, providing required facilities, supporting staff and other appropriate management functions.

\section{CONCLUSION}

The extension functionaries need to be trained adequately on the wider use of electronic communication methods like e mails, and SMS in the local language, so as to facilitate its usage among the farmers. Efforts should be taken up to sensitize the importance of the usage of different group and mass contact methods for different purposes. The extension worker should also be trained on the procedure and principles of organizing these group and mass contact methods. 


\section{REFERENCES}

Anand, K. (2014). Information management patterns of Extension personnel - An analysis, Unpublished Ph.D Thesis, Coimbatore, TNAU.

Davidson, P. Andrew, Ahmad, M \& Ali, T. (2001). Dilemmas of agricultural extension in Pakistan: Food for thought, Agricultural research and extension network, Network Paper No. 116, ISBN 0850035430

Ghanghas, B.S. (2011). Analysis of communication sources used by farm technology researchers, extension personnel and farmers, Journal of progressive agriculture, 2(1): 79 - 83.

Jayakumar, N, Sundaramari, M \& Sindhu, D. (2015). Usage of mobile phones by farmer convenors for agricultural information gathering, Paper presented at the Global Social Science Conference on Management of sustainable livelihood systems, Orissa University of Agriculture and Technology, 14-17 Feb, 2015.

Maalouf, W.D., Adhikarya, R \& Contado, T. (1991). 'Extension coverage and resource problems: the need for publicprivate co-operation', in W.M. Rivera and D.J. Gustafson (eds). Agricultural extension: Worldwide, Amsterdam, Elsevier.

Melak, Degsew \& Workneh, Negatu (2012). Agricultural education and technical competency of development agents in Ethiopia, Journal of Agricultural Extension and Rural Development, 4(11): 347-351.

Shuwa, M.I., Shettima, L., Makinta, B.G \& Kyari, A. (2015). Impact of mass media on farmers agricultural production, Case study of Borno State, Agricultural Development Programme, Academia Journal of Scientific Research, 3(1) : 008-014.

TRAI (Telecom regulatory authority of India) (2016). Highlights of telecom subscription data as on $31^{\text {st }}$ January 2016. Press release No. 22/2016.

Wilson, M.C \& Gallup, G. (1954). Teaching methodology, Agricultural Extension work, United States Home economics, USDA, No.495, 92. 